\title{
PENGARUH RASA MANFAAT DAN KEMUDAHAN TERHADAP MINAT BERPERILAKU (BEHAVIORAL INTENTION) PARA MAHASISWA DAN MAHASISWI DALAM PENGGUNAAN INTERNET
}

\author{
I Putu Sugiartha Sanjaya \\ Univeristas Atma Jaya Yogyakarta
}

\begin{abstract}
Davis' Technology Acceptance Model (TAM), perceived usefulness, and perceived ease of use instruments are widely accepted in information technology research community as tools for evaluating information system application and predicting usage. This study attempts to investigate whether perceived usefulness and perceived ease of use influence behavioral intention in using Internet. Perceived usefulness is the degree to which a person believes that using a particular system would enhance his or her job performance. Perceived ease of use is the degree to which a person believes that using a particular system would be free of effort. Data were collected from 149 students of Department of Informatics Technology, Faculty of Industrial Technology, University of Atma Jaya Yogyakarta. The result is that perceived usefulness has a positive and significant influences on behavioral intention, while the influence of perceived ease of use on behavioral intention is not statistically significant.
\end{abstract}

Keywords: perceived usefulness, perceived ease of use, technology acceptance model behavioral intention

\section{PENDAHULUAN}

Di dalam penggunaan internet, para pengguna mempertimbangkan manfaat dan kegunaan internet tersebut. Pertimbangan seperti itu akan mempengaruhi persepsi para pengguna internet terhadap perilakunya. Penelitian tentang minat berperilaku (behavioral intention) dalam penggunaan teknologi dilakukan dengan menggunakan Technology Acceptence Model (TAM). Dasar teori yang digunakan dalam TAM adalah Theory of Reasoned Action (TRA). Penelitian TAM telah dilakukan oleh Adams et al. (1992), Chin dan Todd (1995), Davis (1989, 1993), Davis et al. (1989), Davis dan Venkatesh (1996), Gefen dan Straub (1997), Igbaria et al. (1997), Segars dan Grover (1993), Subramania (1994), Szajna (1994, 1996), Taylor dan Todd (1995), Venkatesh (1999), Venkatesh dan Davis (1996), dan Venkatesh dan Morris (2000).

Penelitian-penelitian psikologi yang dikemukakan oleh Ajzen (1991) menunjukkan adanya norma subyektif yang menjadi suatu ukuran penting bagi minat berperilaku para pengguna suatu teknologi. Norma subyektif merupakan kritikal masyarakat (Markus 1990), pengaruh sosial (Fulk et al. 1987), dan penyesuaian diri dengan struktur masyarakat (Poole dan DeSantic 1990). Di samping faktor norma subyektif, peran gender juga dapat mempengaruhi minat berperilaku seseorang dalam menggunakan teknologi informasi (Gefen dan Straub, 1997).

Dalam studi ini, penulis menggunakan konsep technology acceptance model (TAM) yang dikemukan oleh Davis (1989) tentang konsep manfaat (perceived usefulness) dan kemudahan (perceived ease of use) terhadap intensitas penggunaan (behavioral intention) teknologi informasi. Menurut Venkatesh dan Morris (2000), model ini digunakan untuk melihat pemahaman individual yang secara terus menerus menggunakan teknologi informasi dalam pekerjaannya. 
Penggunaan teknologi informasi (internet) dan pemanfaatannya dalam pekerjaan masih menjadi perhatian penting dalam penelitian. Walaupun terdapat kemajuan yang cukup berarti dalam kemampuan hardware dan software. Masalah yang muncul dalam penggunaan suatu teknologi adalah pemanfaatan yang rendah terhadap sistem informasi yang ada secara kontinus. Rendahnya penggunaan teknologi informasi dapat menyebabkan rendahnya return dari investasi organisasi dalam teknologi informasi (Venkatesh dan Davis, 2000).

Dalam hal ini, Technology Acceptance Model (TAM) menawarkan suatu penjelasan yang kuat dan sederhana untuk penerimaan teknologi dan perilaku para penggunanya (Venkatesh dan Morris, 2000). Model TAM dilandasi oleh Theory of Reaseond Action (TRA) yang dikemukan Ajzen dan Fisbein (1980). TRA menyatakan bahwa seseorang akan menerima komputer jika komputer memberikan manfaat kepada para pemakainya. Berdasarkan TRA, penggunaan internet ditentukan oleh persepsi individu dan sikap yang pada akhirnya akan membentuk perilaku seseorang dalam penggunaan suatu teknologi informasi (internet).

Menurut Venkatesh dan Morris (2000), ada dua konsep utama yang dipercaya dalam user acceptance yaitu perceived usefulness dan perceived ease of use. Manfaat (perceived usefulness) didefinisikan sebagai tingkat kepercayaan seseorang bahwa suatu penggunaan suatu sistem informasi meningkatkan kinerja dalam pekerjaannya. Kemudahan (perceived ease of use) didefinisikan sebagai tingkat kepercayaan seseorang bahwa penggunaan teknologi sistem informasi akan mudah dan tidak membutuhkan usaha yang keras.

Penelitian ini merupakan replikasi dari beberapa penelitian sebelumnya, diantaranya dilakukan oleh Venkatesh dan Morris (2000). Dalam hal ini, penulis memasukkan satu unsur penting perkembangan teknologi informasi yaitu Internet. Untuk itu, penulis berkeinginan untuk membuktikan apakah manfaat dan kemudahan dapat mempengaruhi minat berperilaku para mahasiswa dan mahasiswi dalam penggunaan Internet.

\section{TINJAUAN LITERATUR DAN PENGEMBANGAN HIPOTESIS 2.1. Theory Of Reasoned Action (TRA)}

Menurut Fishbein dan Ajzen (1975), TRA adalah suatu well-researched intention sebagai model khusus yang telah terbukti berhasil untuk memprediksi dan menjelaskan tentang perilaku seseorang dalam memanfaatkan suatu teknologi dengan beraneka ragam bidang. Fishbein dan Ajzen (1975) juga menjelaskan bahwa TRA adalah sebuah model yang mempelajari secara luas psikologi sosial berkaitan dengan perilaku seseorang yang dilakukan secara sadar.

Berdasarkan TRA, perilaku khusus seseorang dilakukan berdasar behavioral intention dalam memainkan perilaku, dan behavioral intention secara bersama-sama ditentukan oleh attitude seseorang dan subjective norm. Menurut Fishbein dan Ajzen (1975), behavioral intention adalah suatu ukuran tentang kekuatan tujuan seseorang untuk melakukan tindakan khusus. Attitude adalah perasaan positif atau negatif seseorang tentang penentuan tujuan dan target perilaku. Subjective norm adalah persepsi seseorang tentang pendapat umum apakah ia harus atau tidak harus melakukan perilaku seperti dibicarakan banyak orang.

\subsection{Technology Acceptance Model (TAM)}

TAM pertama kali dikembangkan oleh Davis (1989) dan kemudian dipakai serta dikembangkan oleh beberapa peneliti seperti Adam et al. (1992) Szajna (1994), Igbaria et al. (1995), Venkatesh dan Morris (2000) dan Venkatesh dan Davis (2000).

Menurut Davis (1989), TAM memiliki dua konsep yaitu perceived usefulness dan perceived ease of use. Menurut Venkatesh dan Morris (2000), TAM menjelaskan secara kuat dan sederhana menerima suatu teknologi dan perilaku para pemakai. Konsep TAM dilandasi oleh TRA yang menyatakan bahwa seseorang akan menggunakan dan memanfaatkan komputer jika dia merasa bahwa komputer memberikan manfaat positif. 
Pengaruh Rasa Manfaat dan Kemudahan Terhadap Minat Berperilaku (I Putu Sugiartha Sanjaya)

Menurut Davis (1989), manfaat (perceived usefulness) adalah tingkat keyakinan seseorang bahwa penggunaan suatu teknologi tertentu akan meningkatkan prestasi pekerjaannya. Kemudahan (perceived ease of use) adalah derajat kepercayaan seseorang bahwa dengan penggunaan suatu teknologi akan membebaskannya dari usaha menurut Davis (1989).

\section{Manfaat (Perceived Usefulness)}

Menurut Davis (1989); Mathieson (1991); serta Venkatesh dan Davis (2000) manfaat (perceived of usefulness) merupakan penentu yang kuat terhadap penerimaan penggunaan suatu sistem informasi, adopsi, dan perilaku para pengguna. Venkatesh dan Morris (2000) juga menguji apakah manfaat dapat mempengaruhi tingkat perilaku dalam penggunaan sistem informasi yang lebih kuat bagi laki-laki dibandingkan perempuan.

Davis et al. (1989) membukukan bahwa manfaat mempunyai hubungan yang kuat dan konsisten dengan penerimaan teknologi informasi dibandingkan dengan variabel lain seperti sikap, kepuasan, dan ukuran persepsian yang lain. Hasil penelitian yang dilakukan oleh Igbaria (1990) juga menemukan hal yang sama bahwa hubungan yang positif antara perceived usefulness dengan penggunaan sistem informasi. Adam et al. (1992) dalam penelitiannya menemukan bahwa perceived usefulness adalah faktor utama yang menentukan sikap seseorang dalam penggunaan sistem.

Atas dasar teori dan hasil-hasil penelitian sebelumnya maka peneliti mengajukan hipotesis penelitian sebagai berikut:

H1: Manfaat (perceived usefulness) akan mempengaruhi minat berperilaku para mahasiswa dan mahasiswi untuk menggunakan internet.

\subsection{Kemudahan (Perceived Ease Of Use)}

Menurut Venkatesh dan Morris (2000), kemudahan (Perceived Ease of Use) menggambarkan dampak atas tingkat perilaku melalui dua penyebab yaitu dampak langsung atas tingkat perilaku dan dampak tidak langsung atas perilaku melalui perceived usefulness.

Banyak penelitian sebelumnya yang mendukung pengembangan hipotesis ini diantaranya dilakukan oleh Davis et al. (1989), Szajna (1996), Venkatesh dan Davis (2000), dan Venkatesh dan Morris (2000). Secara umum para peneliti ini membukukan hasil bahwa kemudahan berpengaruh terhadap penggunaan sistem informasi baik secara langsung maupun tidak langsung dengan manfaatan (perceived usefulness) sebagai variabel intervening.

Dalam hal demikian, penulis merumuskan hipotesis yang kedua sebagai berikut:

H2: Kemudahan (perceived ease of use) akan mempengaruhi minat berperilaku para mahasiswa dan mahasiswi untuk menggunakan internet.

\section{METODA PENELITIAN}

\subsection{Pemilihan Sampel dan Metoda Pengumpulan Data}

Populasi dalam penelitian ini adalah mahasiswa dan mahasiswi Fakultas Teknologi Industri Universitas Atma Jaya Yogyakarta. Responden dalam penelitian ini adalah individuindividu dalam pekerjaannya yang menghendaki mereka untuk menggunakan teknologi informasi seperti internet. Dipilinnya responden mahasiswa/mahasiswi dalam penelitian ini karena mahasiswa/mahasiswi diasumsikan selalu membutuhkan teknologi sistem informasi untuk menunjang aktivitasnya sebagai mahasiswa/mahasiswi. Berdasarkan kuisioner yang diterima kembali, jumlah mahasiswa/mahasiswi semester 1-3 adalah sebanyak 52 orang, semester 4-5 sebanyak 42 dan semester 5-6 adalah sebanyak 55 orang.

Penelitian ini adalah penelitian lapangan. Data akan dikumpulkan dengan mengirimkan kuesioner kepada masing-masing mahasiswa dan mahasiswi. Dalam penelitian ini, penulis mengirimkan kuisioner sebanyak 200. Tabel berikut ini menunjukkan jumlah kuisioner yang digunakan dalam penelitian ini adalah sebagai berikut. 
Tabel 1

Sampel dan Tingkat Pengembalian

\begin{tabular}{lr}
\hline Jumlah sampel & 200 \\
Jumlah kuisioner yang tidak kembali & 51 \\
Jumlah kuisioner yang kembali dan dapat diolah & 149
\end{tabular}

Tingkat pengembalian sampel dan yang dapat digunakan adalah

$149 / 200 * 100 \%=74,5 \%$

\subsection{Model Penelitian}

Untuk menunjukkan hubungan antara variabel-variabel yang digunakan di dalam penelitian ini secara eksplisit model penelitiannya adalah seperti pada gambar berikut ini.

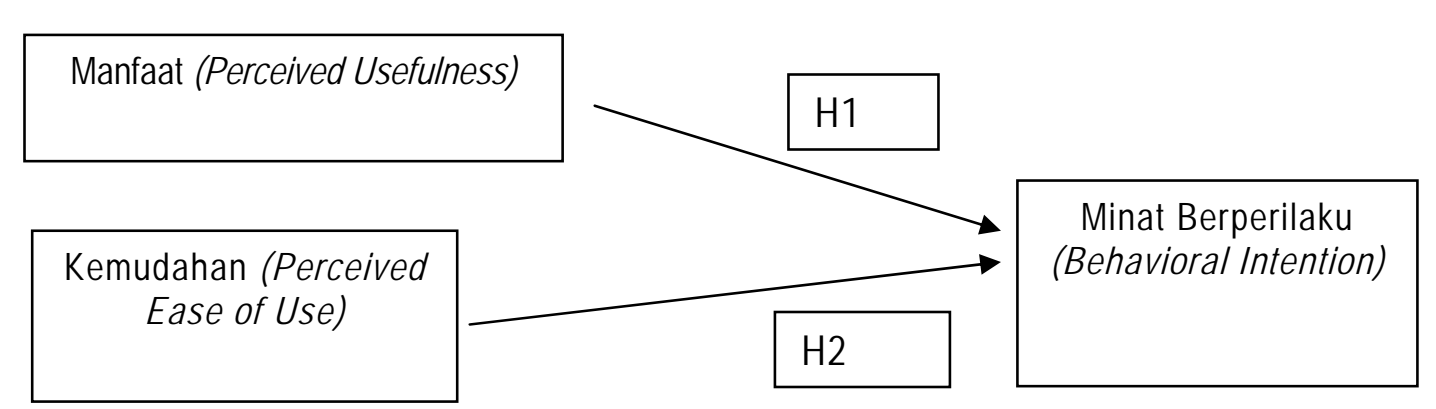

Gambar 1 Model Penelitian

\subsection{Pengukuran Variabel}

Penelitian ini dirancang sebagai suatu penelitian empiris. Untuk menguji hipotesis dalam penelitian ini, maka variabel-variabel yang akan diteliti adalah variabel-variabel yang mempunyai pengaruh terhadap minat berperilaku para pengguna internet.

Instrumen-instrumen pengukuran yang digunakan dalam penelitian ini berdasarkan pada instrumen yang sudah dibuat oleh para peneliti sebelumnya. Variabel minat berperilaku sebagai variabel dependen telah diukur dengan instrumen yang dikembangkan oleh Davis (1989), dan dikembangkan lagi oleh Davis et al. (1989), Mathieson (1991), Taylor dan Todd (1995a, 1995b). Pertanyaan yang berhubungan dengan variabel ini ada 2 item.

Variabel manfaat sebagai variabel independen telah dikembangkan oleh Davis (1989), dan dikembangkan lagi oleh Davis et al. (1989), Mathieson (1991), Taylor dan Todd (1995a, 1995b). Pertanyaan variabel ini ada 3 item. Variabel kemudahan sebagai variabel independen telah dikembangkan oleh Davis (1989), dan dikembangkan lagi oleh Davis et al. (1989), Mathieson (1991), Taylor dan Todd (1995a, 1995b). Pertanyaan yang berhubungan dengan variabel ini ada 4 item.

Variabel minat berperilaku, manfaat, dan kemudahan diukur dengan menggunakan skala Likert. Rentang nilai yang digunakan adalah dari (1) sampai dengan (5). Di dalam penelitian ini, penulis menggunakan alat ukur yang sudah siap pakai yaitu berupa kuisioner yang sudah diketahui validitas dan reliabilitasnya. Beberapa item-item kuisioner ini merupakan pertanyaan-pertanyaan yang diajukan kepada 
responden oleh Davis (1989), dan dikembangkan lagi oleh Davis et al. (1989), Mathieson (1991), Taylor dan Todd (1995a, 1995b), Withey et al. (1983).

Dalam penelitian ini, ada tiga variabel yang diteliti yaitu intensitas penggunaan internet sebagai variabel dependen. Perceived usefulness dan perceived ease of use adalah variabel independen. Butir-butir dari instrumen variabel akan diukur dengan lima skala likert.

\subsection{Pengolahan Data}

Sebelum melakukan pengujian terhadap persamaan regresi dilakukan terlebih dahulu pengujian asumsi klasik. Pengujian ini meliputi tidak terjadinya multikolinieritas antar variabel independen, tidak terjadinya heteroskedastisitas, dan tidak terjadi autokorelasi antar residual setiap variabel independen.

Setelah dilakukan uji asumsi klasik dan tidak terdapat multikoliniaritas, heteroskedastisitas, dan autokorelasi, maka peneliti akan menguji hipotesis penelitian dengan menggunakan regresi berganda sebagai berikut.

Keterangan:

$$
M P=a+\beta_{1} M+\beta_{2} K+\varepsilon
$$

$\alpha=$ Intercept.

$M P=$ Minat Berprilaku (behavioral intention).

$M=$ Manfaat (perceived usefulness)

$\mathrm{K}=$ Kemudahan (perceived ease of use)

$\beta_{1}=$ Koefisien manfaat (perceived usefulness) terhadap minat berperilaku.

$\boldsymbol{\beta}_{2}=$ Koefisien kemudahan (perceived ease of use) terhadap minat berperilaku.

$\varepsilon=$ Kesalahan residu.

\section{ANALISIS DATA DAN PEMBAHASAN}

Analisis didasarkan pada 149 jawaban dari responden. Dari data yang diperoleh hasil diskripsi statistik adalah sebagai berikut.

Tabel 2

\section{Statistik Deskriptif Variabel-Variabel Penelitian}

\begin{tabular}{|c|c|c|c|c|c|}
\hline Variabel & & Minimum & Maksimum & Mean & Deviasi Standar \\
\hline $\begin{array}{l}\text { Minat } \\
\text { Berperilaku } \\
\text { (Behavioral } \\
\text { Intention) }\end{array}$ & 149 & 1.00 & 5.00 & 4.3356 & .68636 \\
\hline $\begin{array}{l}\text { Manfaat } \\
\text { (Perceived } \\
\text { Usefulness) }\end{array}$ & 149 & 1.25 & 5.00 & 4.1728 & .72939 \\
\hline $\begin{array}{l}\text { Kemudahan } \\
\text { (Perceived Ease } \\
\text { of Use) }\end{array}$ & 149 & 1.00 & 5.00 & 4.0358 & .69656 \\
\hline
\end{tabular}

Dari Tabel 2 dapat dijelaskan bahwa jawaban yang diberikan responden untuk variabel minat berperilaku berkisar antara 1.00 sampai dengan 5.00. Nilai mean untuk variabel ini adalah 4.3356 dengan deviasi standar.68636. Untuk variabel manfaat dalam penggunaan internet jawaban dari responden berkisar antara 1.25 sampai dengan 5.00 . Nilai rata-rata variabel manfaat adalah sebesar 4.1728. Deviasi standar untuk variabel manfaat adalah .72939. Variabel 
kemudahan dalam penggunaan internet jawaban dari responden menunjukkan kisaran angka 1.00 sampai dengan 5.00. Nilai rata-rata variabel kemudahan adalah sebesar 4.0358. Deviasi standar untuk variabel kemudahan adalah .69656.

\section{1. Hasil Uji Validitas dan Reliabilitas}

Uji reliabilitas instrumen dalam studi ini dilakukan dengan cronbach alpha pada masingmasing instrumen. Menurut Ghozali (2002), teknik cronbach alpha adalah suatu teknik yang akan menunjukkan indeks konsistensi internal yang akurat, cepat, dan ekonomis. Instrumen dikatakan memenuhi reliabilitas jika nilai cronbach alpha lebih besar dari 0.60 .

Pengujian validitas dilakukan untuk mengetahui apakah pertanyaan-pertanyaan dalam variabel ini valid dilakukan analisis faktor. Pengujian ini juga dilakukan untuk mengetahui seberapa cermat suatu alat uji melakukan fungsi pengukurannya. Dalam penelitian ini, penulis tidak melakukan pengujian secara statistik terhadap validitas karena menurut penulis beberapa instrumen-instrumen studi ini sebelumnya sudah digunakan oleh Davis (1989), dan dikembangkan lagi oleh Davis et al. (1989), Mathieson (1991), Taylor dan Todd (1995a, 1995b) menggunakan instrumen minat berperilaku. Davis (1989), dan dikembangkan lagi oleh Davis et al. (1989), Mathieson (1991), Taylor dan Todd (1995a, 1995b) menggunakan instrumen manfaat. Davis (1989), dan dikembangkan lagi oleh Davis et al. (1989), Mathieson (1991), Taylor dan Todd (1995a, 1995b) menggunakan instrumen kemudahan. Berdasarkan hal ini, penulis berpendapat bahwa instrumen ini memenuhi unsur validitas untuk mengidentifikasikan validitas konstruk dari masing-masing variabel.

Hasil pengujian reliabilitas secara statistik dapat dilihat sebagai berikut.

Tabel 3

Hasil Pengujian Reliabilitas

\begin{tabular}{lc}
\hline \multicolumn{1}{c}{ Variabel } & Cronbach Alpha \\
\hline Minat Berperilaku (behavioral intention) & 0.6419 \\
Manfaat (perceived usefulness) & 0.8704 \\
Kemudahan (perceived ease of use) & 0.8021 \\
\hline
\end{tabular}

Berdasarkan hasil dalam Tabel 3 menunjukkan bahwa variabel-variabel penelitian yaitu minat berperilaku, manfaat, dan kemudahan memenuhi unsur reliabel. Hal ini ditunjukkan dengan nilai cronbach alpha untuk minat berperilaku sebesar 0.6419 , manfaat sebesar 0.8704 , dan kemudahan sebesar 0.8021 . Hasil cronbach alpha ini lebih besar dari 0.60 sebagai syarat bahwa instrumen-instrumen studi dapat dikatakan reliabel. Setelah melakukan pengujian reliabilitas, maka variabel-variabel baik dependen maupun independen dikatakan layak untuk digunakan dalam studi ini.

\section{2. Hasil Pengujian Hipotesis}

Hipotesis yang akan diuji dalam penelitian ini ada dua yaitu pertama, manfaat (perceived usefulness) akan mempengaruhi minat berperilaku para mahasiswa dan mahasiswi untuk menggunakan internet dan kedua, kemudahan (perceived ease of use) akan mempengaruhi minat berperilaku para mahasiswa dan mahasiswi untuk menggunakan internet.

Kedua hipotesis ini akan diuji secara serentak dengan menggunakan multiple regression. Hasil analisis regresi dari data yang diperoleh untuk masing-masing variabel independen (manfaat dan kemudahan) terhadap variabel dependen (minat berperilaku) meliputi koefisien parameter (beta), t-value, R Square, adjusted R-Squared, F-value dan signifkansi secara statistik adalah sebagai berikut. 
Pengaruh Rasa Manfaat dan Kemudahan Terhadap Minat Berperilaku (I Putu Sugiartha Sanjaya)

Tabel 4

Hasil Analisis Regresi Berganda

\begin{tabular}{|c|c|c|c|c|c|c|c|c|}
\hline \multirow[t]{2}{*}{ Variabel } & \multicolumn{2}{|c|}{$\begin{array}{c}\text { Unstandardized } \\
\text { Coefficient }\end{array}$} & \multirow[t]{2}{*}{$T$} & \multirow[t]{2}{*}{$F$} & \multirow[t]{2}{*}{ Sig } & \multirow{2}{*}{$\begin{array}{c}R- \\
\text { Square } \\
d\end{array}$} & \multirow{2}{*}{$\begin{array}{c}\text { Adjusted } \\
R- \\
\text { squared }\end{array}$} & \multirow[t]{2}{*}{ Ket } \\
\hline & B & $\begin{array}{l}\text { Std } \\
\text { Error }\end{array}$ & & & & & & \\
\hline Model & & & & 13.744 & 0.000 & 0.158 & 0.140 & \\
\hline Konstanta & 2.578 & 0.346 & $\begin{array}{l}7.44 \\
0\end{array}$ & & 0.000 & & & $\begin{array}{l}\text { Signifi } \\
\text { kan }\end{array}$ \\
\hline $\begin{array}{l}\text { Manfaat } \\
\text { (perceived } \\
\text { usefulness) }\end{array}$ & 0.285 & 0.085 & $\begin{array}{l}3.37 \\
7\end{array}$ & & 0.0009 & & & $\begin{array}{l}\text { Signifi } \\
\text { kan }\end{array}$ \\
\hline $\begin{array}{l}\text { Kemudahan } \\
\text { (perceived } \\
\text { ease of use) }\end{array}$ & 0.140 & 0.088 & $\begin{array}{l}1.58 \\
6\end{array}$ & & 0.114 & & & $\begin{array}{l}\text { Tidak } \\
\text { Signifi } \\
\text { kan }\end{array}$ \\
\hline
\end{tabular}

Hipotesis pertama diajukan bahwa manfaat (perceived usefulness) akan mempengaruhi minat berperilaku para mahasiswa dan mahasiswi untuk menggunakan internet tidak dapat ditolak. Hasil ini dibuktikan dengan nilai $p$-value 0.000 pada $t$-value sebesar 3.377 dan koefisien beta sebesar 0.285 seperti pada tabel 4. Hasil ini menunjukkan bahwa besaran pengaruh manfaat terhadap minat berperilaku mahasiswa dan mahasiswi dalam menggunakan internet sebesar 0.285. Ini berarti bahwa manfaat memiliki pengaruh positif dan signifikan secara statistik terhadap minat berperilaku dalam menggunakan internet oleh mahasiswa dan mahasiswi.

Hasil penelitian ini mendukung hasil penelitian sebelumnya yang dilakukan oleh Davis (1989), Davis et al. (1989), Subramania (1994), Szajna (1994), Igbaria et al. (1995), dan Venkatesh dan Morris (2000) yang menunjukkan bahwa persepsi manfaat sangat berhubungan erat dan berpengaruh signifikan terhadap minat berperilaku para pemakai teknologi.

Hipotesis kedua yang menyatakan bahwa kemudahan (perceived ease of use) akan mempengaruhi minat berperilaku para mahasiswa dan mahasiswi untuk menggunakan internet tidak didukung. Hasil ini dibuktikan dengan nilai $p$-value 0.1148 pada $t$-value sebesar 1.587 seperti dalam tabel 4 . Hasil ini menunjukkan bahwa besaran pengaruh kemudahan terhadap minat berperilaku mahasiswa dan mahasiswi dalam menggunakan internet sama dengan 0.

Hal ini berarti bahwa kemudahan tidak memiliki pengaruh terhadap minat berperilaku dalam menggunakan internet oleh mahasiswa dan mahasiswi. Hasil penelitian ini tidak mendukung hasil penelitian sebelumnya yang dilakukan oleh Venkatesh dan Davis (1996) dan Venkates dan Morris (2000).

\section{SIMPULAN}

Secara keseluruhan hasil studi mendukung satu dari dua hipotesis penelitian yang diajukan. Studi ini berhasil membuktikan bahwa manfaat (perceived usefulness) dapat mempengaruhi minat berperilaku para mahasiswa dan mahasiswi dalam menggunakan internet. Hasil studi mendukung hasil studi penelitian sebelumnya yang dilakukan oleh Davis (1989), Davis et al. (1989), Subramania (1994), Szajna (1994), Igbaria et al. (1995), dan Venkatesh dan Morris (2000).

Hasil ini semakin memperkuat teori yang menyatakan bahwa manfaat (perceived usefulness) dapat mempengaruhi seseorang dalam menggunakan suatu teknologi. Hal ini didukung oleh suatu premis yang menyatakan bahwa seseorang akan menggunakan suatu teknologi (komputer) jika teknologi (komputer) ini memberi manfaat atau hasil yang positif bagi para penggunanya. Akan tetapi, studi ini gagal membuktikan 
pengaruh kemudahan (perceived ease of use) terhadap minat berperilaku para mahasiswa dan mahasiswi dalam menggunakan internet.

Penolakan terhadap hipotesis kedua kemungkinan disebabkan karena penggunaan internet pertama kali kelihatannya mudah untuk digunakan dan mungkin untuk jangka panjang akan ditinggalkan jika sistem tersebut tidak lagi memberikan manfaat (Igbaria et al. 1995). Menurut Davis (1989), keunggulan manfaat (perceived usefulness) membuat kekuatan secara konseptual untuk mendorong para pemakai untuk menggunakan suatu aplikasi karena fungsinya yang sangat tinggi dalam membantu meningkatkan kinerja para pemakainya. Sehingga faktor kemudahan atau kesulitan (ease or hard) dalam mengoperasionalkan internet menjadi tidak begitu penting.

Penelitian ini hanya mempertimbangkan dua variabel yang dapat mempengaruhi minat berperilaku para mahasiswa dan mahasiswi dalam menggunakan internet. Berdasarkan hasil pengujian hipotesis terbukti dua variabel independen ini hanya mempengaruhi minat berperilaku para mahasiswa dan mahasiswi hanya sebesar $15,84 \%$ sedangkan sisanya dipengaruhi oleh faktor-faktor lain yang belum diperhitungkan dalam penelitian ini.

Pengambilan sampel hanya pada satu tempat perguruan tinggi yaitu Univeritas Atma Jaya Yogyakarta. Hal ini berdampak kepada masalah validitas eksternal dari hasil penelitian ini. Kelemahan ketiga, penulis tidak memasukkan unsur gender di dalam penelitian ini. Menurut Venkatesh dan Morris (2000), lakilaki lebih cenderung mementingkan pekerjaannya dari pada wanita.

Beberapa kelemahan dalam penelitian ini dapat diperbaiki bagi penelitian berikutnya. Pertama, peneliti berikutnya dapat memperluas daerah penelitian ini dengan menyebar kuisioner ke perguruan tinggi yang lain. Kedua, penelitian yang akan datang dapat menambah beberapa variabel independen seperti norma sosial, kompleksitas yang dirasakan, kejelasan hasil, dan ketidakpastian tugas. Kemungkinan variabel-variabel ini dapat mempengaruhi minat berperilaku para mahasiswa dan mahasiswi dalam menggunakan internet. Ketiga, peneliti berikutnya bisa melakukan komparasi perilaku mahasiswa antar jenjang pendidikan tinggi dari program S1, S2, dan S3 dalam menggunakan teknologi internet. Karena kompleksitas tugas antara tiga program ini adalah berbeda. Keempat, peneliti berikutnya dapat memasukkan unsur gender di dalam penelitian ini yaitu perilaku antara laki-laki dengan wanita dalam penggunaan internet.

\section{DAFTAR PUSTAKA}

Adam, D. A., R. R. Nelson, dan P. A. Todd, (1992), "Perceived Usefulness, Ease of Use and Usage of Information Technology: A Replication", MIS Quarterly, 16/2: 227-250.

Ajzen, I. dan M. Fishbein, (1980), Understanding Attitudes and Predicting Sosial Behavior, Prentice-Hall, Englewood Cliffs, NJ.

Ajzen, I., (1991), "The Theory of Planned Behavior", Organizational Behavior and Human Decision Processes, 50: 179-211.

Chin, W. W. dan P. A. Todd, (1995), "On the Use, Usefulness, and Ease of Use of Structural Equation Modeling in MIS Research: A Note of Caution", MIS Quarterly, 19: 237-246.

Davis, F. D., (1989), "Perceived Usefulness, Perceived Ease of Use, and User Acceptance of Information Technology", MIS Quarterly, 13/3: 319-339.

Davis, F. D., (1993), "User Acceptance of Information Technology: System Characteristics, User Perceptions and Behavioral Impacts", International Journal of Man-Machine Studies, 38/3: 475-487.

Davis, F. D., R. P. Bagozzi, dan P. R. Warshaw, (1989), "User Acceptance of Information Technology: A Comparison of Two Theoretical Model", Management Science, 35: 982-1002. 
Davis, F. D., dan V. Venkatesh, (1996), "A Critical Assessment of Potential Measurement Biases in the Technology Acceptance Model: Three Experiments", International Journal of Human Computer Studies, 45: 19-45.

Fishbein, M. dan I. Ajzen, (1975), Belief, Attitude, Intention and Behavior: An introduction to Theory and Research, Addison-Wesley, reading, MA.

Fulk, J., C. W. Steinfield, J. Schmitz, dan J. G. Power, (1987), "A Social Information Processing Model of Media Use in Organizations", Communications Research, 14: 529-552.

Gefen, D. dan D. W. Straub, (1997), "Gender Differences in the Perception and Use of E-mail: An Extension to the Technology Acceptance Model", MIS Quarterly, 12/4: 389-400.

Ghozali, I., 2002. Aplikasi Analisis Multivariate dengan Program SPSS". Badan Penerbitan Universitas Diponegoro Semarang, edisi 2.

Igbaria, M., N. Zinatelli, P. Cragg, dan A. L. M. Cavaye, (1997), "Personal Computing Acceptance Factors in Small Firms: A Structural Equation Model", MIS Quarterly, 21/3: 279-305.

Markus, M. L., (1990), "Toward a "Critical Mass" Theory of Interactive Media", Organization and Communication Technology, J. Fulk dan C. Steinfield (eds), sage, Newbury Park, CA.: 491-511.

Mathieson, K., (1991), "Predicting User Intentions: Comparing the Technology Acceptance Model with the Theory of Planned Behavior", Information Systems Research, 2: 173-191.

Poole, M. S. dan G. DeSantics, (1990), "Understanding the Use of Group Decisions Support Systems: The Theory of Adaptive Structuration", Organizations and Communication Technology, J. Fulk dan C. Steinfield (eds), Sage, Newbury Park, CA.: 173-191.

Segars, A. H. dan V. Grover, (1993), "Re-examining Perceived Ease of Use and Usefulness: A Confirmatory Factor Analysis", MIS Quarterly, 18/4: 517-525.

Subramanian, G. H., (1994), "A Replication of Perceived Usefulness and Perceived Ease of Use Measurement", Decision Sciences, 25/5/6: 863-874.

Szajna, B., (1994), "Software evaluation and Choice: Predictive Validation of the Technology Acceptance Instrument", MIS Quarterly, 18: 319-324.

Szajna, B., (1996), "Empirical Evaluation of the Revised Technology Acceptance Model", Management Science, 42: 85-92.

Taylor, S. dan P. A. Todd, (1995a), "Understanding Information Technology Usage: A Test of Competing Models", Information System Research, 6: 144-176.

Taylor, S. dan P. A. Todd, (1995b), "Assessing IT Usage: The Role of Prior Experience", MIS Quarterly, 19/4: 561-570.

Venkatesh, V., (1999), "Creation of Favorable User Perceptions: Exploring the Role of Intrinsic Motivation", MIS Quarterly, 23/2: 239-260. 
KINERJA, Volume 9, No.2, Th. 2005: Hal. 113-122

Venkatesh, V., dan F. D. Davis, (1996), "A Model of the Perceived Ease of Use Development and Test", Decision Sciences, 27/3: 451-481.

Venkatesh, V., dan Michael G. Moris, (2000), "Why Don't Men Ever Stop to Ask for Directions? Gender, Social Influence, and Their Role in Technology Acceptance and Usage Behavior", MIS Quarterly, 24/1.

Withey, M., R. L. Daft, dan W. H. Cooper, (1983), "Measures of Perrow's Work Unit Technology: An Empirical Assessment and a New Scala", Academy of Management Journal, 21/1: 4563. 